\title{
Revitalization of Po Pado: Explaining the Meaning of Educational Value of Oral Tradition in the People of Rakalaba Village, West Golewa District, Ngada Regency
}

\author{
Maria Y. C. Age* \\ STIPAR Ende, Indonesia \\ "Corresponding author.Email:cagemariayulita@gmail.com
}

\begin{abstract}
This study aims to find and describe the meaning of educational values in Po Pado in the people of Rakalaba village, West Golewa District, Ngada Regency. This study used a qualitative approach. The results of the study proved that $P o$ Pado in the people of Rakalaba Village, West Golewa District, Ngada Regency is in the form of an old poem, namely a proverb. The meaning of educational value of Po Pado are (1) the meaning of togetherness, (2) the meaning of leluri, (3) the meaning of kinship, and (4) the meaning of economy. While the functions of Po Pado's Educational Values are (1) personal functions, (2) family functions, (3) social functions, (4) economic functions, and (5) leadership functions.
\end{abstract}

Keywords: Po Pado, Proverb, Oral tradition, Educational value.

\section{INTRODUCTION}

Language is a means of communication between people. Without language, people can do nothing. With the rapid development of science and technology today, the importance of language is increasingly felt as a means of communication. According to Suwarna [1] language is a pivotal tool to communicate in daily life. Language is a reality and action that has empirical dimensions, or material aspects in the form of vowels and consonants, words, and non-empirical structures in the form of inner meanings in the form of meanings and values. So, the language used by humans in communication is an empirical expression that has meaning in the form of information content [2].

The regional language has a function in its position because it is a symbol of regional pride, regional identity, a means of developing and supporting regional culture, and a supporter of the national language. It is an undeniable fact that the local language has an important role in the life of the Indonesian nation. Most Indonesian speakers use the local language as their mother tongue. Thus, it is very clear that local languages cannot be separated from the life of certain local people [3].
Each ethnic group has a regional language to communicate between members of the community. The regional language is one of the local wisdom or local cultures in Indonesia. The local culture is defined as the whole effort and results that society created which aim to give value to society's life [4]. Thus, the Ngada language is a regional language that is used as a vehicle for cultural preservation. As a vehicle for cultural preservation, Ngada language is used as a means of communication or communicating cultural elements in traditional ceremonies, marriage ceremonies, and proverbs ( $P O$ Pado) which are the basic principles of children's education.

In Indonesia, proverbs are usually used to transfer certain values of life. Mansyur et al. [5] stated that "Indonesia proverb is one type of oral literature that contains positive cultural values that reflect the speaker's world view". For this reason, proverbs could be the way to teach the young generation to get educational values. According to Darmasoetjipta [6], the proverb is a formulation of wisdom in society that indicates an attitude of vigilance and caution, which is closely related to moral values and virtues in life.

The people of Rakalaba Village are generally farmers, although some other people work as teachers or 
employees. Customs are still very strong, and closely related to local languages. In general, the people of Ngada follow the basic principles of education as follows:

"Go jara bodha wi wai meme pu'u kedhi, raba go tengu nenga meku, wai mali jara da meze gha nenga wiu talo".

(A horse if trained since childhood will be easy to control, but if a horse is trained as an adult then it can no longer be controlled).

If the parents do not carry out the expression above thus, the children will develop like the expression in the Ngada language:

"Moe jara aze bha'i"

(Like no rope horse)

Like a horse without a rope

"Moe ho'o mori bhai"

(Like the master's servant doesn't exist)

Like a servant without a master

"Moe jara tengu tego"

(Like a hard neck horse)

Like a hard-necked horse

The expression above describes the principles of education for Ngada children, so parents, grandfathers, grandmothers, acquaintances, and even all members of the village people together shape children and young people to become useful people. The expression above is identified as proverbs or Po Pado. In other words, proverb is created by people in Rakalaba Village. Based on the description above, this study describes the Meaning of Educational Values in Po Pado in the people of Rakalaba Village, West Golewa district, Ngada Regency.

\section{METHODS}

In this study, the researcher used a qualitative approach. The data used in this study is oral data in the form of expressions of Educational Values in Po Pado in the people of Rakalaba Village, West Golewa District, Ngada Regency. Sources of data are elders or elders, community leaders, and also people who are capable and skilled in singing Po Pado. According to Arikunto [7] the research' data sources have criteria. The theory used in this research is cultural-linguistic theory and value theory.

\section{RESULTS AND DISCUSSION}

Etymologically, Po Pado consists of two words namely po and pado, Po means good whispers, good advice, lessons or teachings, good suggestions (hints, warnings, reprimands), while Pado means a proverb that contains good things that have ordinary aesthetic value is in the form of arranging to fulfill or recommend positive values that are useful in everyday life. So, Po Pado is a saying that has positive values that are useful in everyday life.

Education is a deliberate effort made by educators or schools in a planned way to create a learning environment or culture that allows students to gain valuable experience to develop their potentials optimally in terms of spirituality, personality, intelligence, and skills.

The value of education in Po Pado in the people of Rakalaba village, West Golewa district, Ngada Regency is a physical form that can be seen. We can see this in the value of the proverb below:

(1) Leadership Value

"Nunu wi rada bata, fao masa kedhi banga"

Banyan for boundary sign, shade all small children

The banyan that gives shade to everyone

Make yourself a shelter, a protector for the weak

"Fiki wi nono dhiri, lina wi pia kisa"

Dregs along the edges, clean, put in the middle

Separate the dregs from the clean ones

The evil is removed, embrace the good

"Wi jere moe watu tay, we tena the sama as se'a wea"

Even as a rock, balanced like a golden shell

Give fair justice

Judging from the data above, the sentence "nunu wi rada bata, fao masa kedhi banga" means to make yourself a shelter, a protector for the weak. Strength is likened to "nunu" or "banyan". This sentence has a meaning like a "banyan", a symbol of strong protective integrity, a protector for all small and weak people. "Fiki wi nono dhiri's sentence, lina wi pia kisa" means that the evil is removed, the good is embraced. Evil acts are likened to fiki, while good deeds are likened to lina. "Wi jere moe watu tay, wi tena sama se'a wea" means to give equal justice. This sentence implies that we should be someone who embraces everyone, mediates, is fair, and does not choose favouritism in family life.

(2) The Value of Mutual Cooperation

"Su'u dho'o eki tewi"

Hold up, take tote

Lifting up to be upheld, picking up to be carried

Working hand in hand 
Judging from the data above, "Su'u dho'o eki tewi" means cooperation. "Su'u dho'o" means equally uphold, "eki tewi" means equally carry. Help each other, do not let others work alone, give help to others. This sentence has the meaning of working together.

(3) The Value of Hard Work

"Go besi bodha mawu mema pu'u kedhi"

Kestela must be waxed once since she was a child

The harmony is delicious if the candle is about to be fruit

\section{Skilled at working hard since childhood}

Looking at the data above, "Go besi bodha mawu meme pu'u kedhi" means skilled at working since childhood. "Mawu iron" is a cassava fruit. The skills of a child who are trained since childhood are like "mawu iron". "Go iron bodha mawu meme pu;u kedhi" means that a child's skills at work must be trained from an early age in the family environment, like a cassava fruit that tastes good and is soft from the time it is ripe. This sentence implies that you should be skilled at working while in the family environment. This work skills education is for the future of the young person himself, because in the future he himself must build his family life and be able to be independent.

\section{(4) The Value of Marriage}

"Mali ghiri ma'e da liki riwu, riwu tuku tawa dhu page wa'I"

If you glance, do not throw a crowd, people will laugh until their legs swing

If you don't glance in front of many people, you will be laughed at

Dare to approach other people's children, don't pretend

Seeing from the data above, "Mali ghiri ma'e da liki riwu, riwu tuku tawa dhu page wa'i" or means that if you want to rate or propose to someone's girl, you should not act like throwing stones and hiding your hands, pretending, but show who dares to approach with a sincere and honest attitude. Dare to appear and work skillfully, because what you do is seen and judged by many people, if you are wrong or turn around, many people will laugh at you. This sentence implies that we should be serious if we want to choose a life partner.

(5) Prohibition Value

"Ma'e beke meze, ma'e kaza kapa"

Don't have big chest, don't have thick shoulders

Don't puff out your chest, don't shrug

Don't be arrogant and look down on others
Looking at the data above, "Ma'e beke meze, ma'e kaza kapa" means don't be arrogant or think yourself great. Beke meze means to puff out the chest. This sentence means not to puff out one's chest (bragging), not relying on physical strength against others, not forcing one's own will, and looking down on others.

"Ma'e naka ta'i ngata"

Don't steal people's shit

Don't take other people's

Looking from the data above, "Ma'e naka ta'i ngata" means don't steal other people's food ingredients. The "ta'I" that is meant is not feces or feces, but food ingredients. This sentence implies that we have to work, don't be lazy and just want to take other people's things.

The meaning of educational value in Po Pado, Rakalaba people, West Golewa district, Ngada Regency:

1.) The Meaning of Togetherness. The meaning of togetherness means that people who believe in this oral literature can foster a sense of brotherhood and kinship between members of the community so that it is well maintained. This meaning is stated in the sentence "Su'u dho'o eki tewi".

2.) Meaning of Leluri. The meaning of Leluri means that this meaning is passed down which has become a tradition from the ancestors or ancestors used by the community to establish kinship ties. This meaning is found in the sentence "Kodo ma'e teo, ga'a ma'e pe'I".

3.) The Meaning of Family. The meaning of kinship is a bond of kinship or kinship that is intertwined and nurtured in social life. The meaning is found in the sentence, "Nunu wi rada bata, fao masa kedhi banga".

4.) Economic Meaning. Economic meaning is a method used by the community to meet all needs. This meaning is found in the sentence "Bugu wai kungu ri wai logo".

The Function of Educational Values in Po Pado in the people of Rakalaba Village, West Golewa District, Ngada Regency:

1.) Personal Functions. This function can be seen in the sentences "ma'e beke meze, ma'e kaza kapa, ma'e naka ta'i ngata". The use of words that show as a personal function is "ma'e beke meze, ma'e kaza kapa". This sentence contains the meaning of not puffing out one's chest (bragging), not relying on physical strength against others, not forcing one's own will, and looking down on others. "Ma'e naka ta'i ngata" this sentence means that we have to work, don't be lazy and just want to take other people's things. 
2.) Family Function. This function is found in the sentence Nunu wi rada bata, fao masa kedhi banga. The use of words that show as a family function is Nunu wi rada bata, fao masa kedhi banga. This sentence implies that we should be someone who embraces everyone, is a mediator, is fair, and doesn't show favoritism in family life.

3.) Social Function. This function can be seen in the sentence "ma'e moe ngana dheso lego". The use of words that show as a social function is "Ma'e moe ngana dheso lego". This sentence means do not be someone who is not clear, do not have the principles of life and lives on the move.

4.) Economic Function. This function can be seen in the sentences "kodo ma'e teo, ga'a ma'e pe'i, bugu wai kungu uri wai logo". The use of words that show as an economic function is "kodo ma'e teo, ga'a ma'e pe'i". This sentence means that apart from working in the fields, we also have to raise livestock. This sentence implies that managing life, obtaining food and all daily needs is not easy by working hard.

5.) Leadership Function. This function can be seen in the sentences "maku-maku ana ngalu, be'o-be'o ana eko, wiwi ma'e lema ma'e sema, wi yie and jara ngaza, kako manu, dutu sa moe go pau da tulu wunu". The use of words that show as a function of leadership. "Maku-maku ana ngalu, be'o-be'o ana eko" this sentence implies that, a wise person leaders, observers and alerts in order to protect their followers in running an organization. "Wiwi ma'e lema ma'e sema" this sentence means that we must speak according to reality and must not take sides or be biased. "Wi yie sama jara ngaza, kako and manu" means good and good at talking. "Dutu sa moe go pau da tulu wunu" this sentence means as humans we must unite, we must not differentiate or bring down each other.

Those results above revealed that Po Podo or proverbs influence the principles of Po Pado in the people of Rakalaba Village, West Golewa District, Ngada Regency. It implies that the people of Rakalaba Village have their principles created by oral traditions. These results are in line with Vitasurya's [8] study, he investigated the principles of people in Kalibiru village, the findings of his study revealed that Kalibiru people have the principles of that is communal works.

\section{CONCLUSION}

Based on the description above, it can be concluded that revitalizing or revitalizing oral traditions that are starting to become heredity in the current digital era is an effort that must be maintained so that cultural heritage does not become heredity, especially with the progress of the times making generations not familiar with their own culture. The meanings contained in Po Pado in the people of Rakalaba Village, West Golewa District, Ngada Regency are the meaning of kinship, the meaning of leluri, the meaning of togetherness, and the meaning of economics. The functions contained in the Po Pado in the people of Rakalaba Village, West Golewa District, Ngada Regency are personnel functions, family functions, social functions, economic functions and leadership functions.

\section{REFERENCES}

[1] P. Suwarna, Strategi Penguasaan Berbahasa, Yogyakarta: Adicita Karya Nusa, 2002.

[2] P. Pampe, Empowerment of Local Languages in Religious Activities, Kupang: Gita Kasih, 2009.

[3] H. Kridaklaksana, Language Functions and Language Attitudes, Ende: Nusa Indah, 1985.

[4] F.X. Rahyono, Kearifan Budaya Dalam Kata, Jakarta: Wedatama Widya Sastra, 2015.

[5] F. A. Mansyur, C. Nuryadin, M. Muchtar, S. Sahril, and W. O. A. Amayliya, "Character Education Values in Indonesian Proverbs," ELS J. Interdiscip. Stud. Humanit., vol. 4, no. 3, pp. 346-354, 2021.

[6] F.S. Darmasoetjipta, Kamus Peribahasa Jawa dengan Penjelasan Kata-kata dan Pengertiannya, Yogyakarta: Penerbit Kanisius, 1985.

[7] S. Arikunto, Research Procedure A Practical Approach, Jakarta: Rineka Cipta, 2006.

[8] V. Vitasurya, "Local Wisdom for Sustainable Development of Rural Tourism, Case on Kalibiru and Lopati Village Provivce of Yogyakarta." Social and Behavioral Sciences, pp. 97 - 108, 2016. 